\title{
Ensinar e Aprender com As Práticas Corporais e Estéticas na Saúde
}

\author{
Carvalho, Yara Maria de \\ Universidade de São Paulo - yaramc@usp.br
}

INTRODUÇÃO: ao longo dos últimos anos temos trabalhado com as práticas corporais e estéticas - leitura e escrita - na formação em saúde, no âmbito da graduação e da pósgraduação, entendendo essas práticas como processos criativos capazes de modificar e transformar os corpos em relação. na dimensão da formação em saúde, o que se pretende, em última instância, é transformar o espaço da sala de aula, em espaço de "experiência de formação" e "experiência de presença". a experiência é compreendida aqui como uma possibilidade de escutar o "inaudito". a formação, por sua vez, é um "devir plural", sem prescrição e nem ideia e intervenção normativa, autoritária, ou ainda excludente. São práticas que contribuem para um pensamento aberto sobre formação. OBJETIVO: Nesse sentido, nosso objetivo tem sido investigar a respeito dessas iniciativas sob três aspectos: a relação com o corpo/texto, a relação com a rede social na qual corpo e ser/texto e leitor estão inseridos, e a relação do ser/leitor consigo mesmo. MÉTODO: o método utilizado é a cartografia e o conceito de "aprendizagem inventiva" é a referência teórico-conceitual para a análise do processo da experiência com o corpo, a literatura e a escrita. RESULTADOS: dos resultados em sala de aula cabe destacar uma certa "surpresa" dos estudantes diante das experiências e, sobretudo, o interesse em outras perspectivas a respeito do processo ensino-aprendizagem e a composição entre o corpo, o livro e a escrita. CONCLUSÃO: como contraponto à ideia de formação em saúde "tradicional", que concebe o corpo apenas na sua dimensão física, desconectado de outros corpos, pura natureza, de comportamento previsível, invariável e explicado cientificamente, a "experiência formativa" exige um se voltar para si mesmo com implicações coletivas e políticas, na dimensão das forças e dos afetos. Já o trabalho com a literatura e escrita, para além dos aspectos culturais, transformam-se em dispositivos potentes que conectam, também na dimensão lúdica, pensamento e movimento.

Carvalho, Yara Maria de. Ensinar e Aprender com As Práticas Corporais e Estéticas na Saúde. In: Anais do Congresso Internacional de Humanidades \& Humanização em Saúde [= Blucher Medical Proceedings, num.2, vol.1]. São Paulo: Editora Blucher, 2014. ISSN 2357-7282

DOI 10.5151/medpro-cihhs-10487 